\title{
Effect of Mangosteen Peel Extract (Garcinia mangostana l.) with Supplemental Zinc and Copper on Performance and Egg Quality of Sentul Laying Chicken
}

\author{
Tuti Widjastuti ${ }^{1, *}$, Lovita Adriani ${ }^{2}$, Indrawati Yuda Asmara ${ }^{1}$, Iwan Setiawan ${ }^{1}$, Abun $^{2}$, \\ Leni Nurlaeni ${ }^{2}$ \\ ${ }^{1}$ Departemen of Production, Faculty of Animal Husbandry, Universitas Padjadjaran, 45363, Indonesia, ${ }^{2}$ Department of Animal Nutrition \\ and Feed Technology, Faculty of Animal Husbandry, Universitas Padjadjaran, 45363, Indonesia
}

Received: March 12, 2021; Revised: May 17, 2021; Accepted: September 21, 2021

\begin{abstract}
Mangosteen peel extract is a medicinal plant that can be used as an herbal supplement, containing xanthone compounds that function as antioxidants and antimicrobials. The research was conducted to determine the effect of Mangosteen Peel Extract with mineral (MPEm) as a feed supplement to the production and egg quality of Sentul Chicken. Sentul Chicken is a local chicken of west java which have potential as dual-purpose chickens. This study used 40 female chickens. The method used was a completely random design with five treatments namely, P0 (basal ration), P1 (basal ration with $60 \mathrm{mg} / \mathrm{kg} \mathrm{MPEm}$ ), P2 (basal ration with $120 \mathrm{mg} / \mathrm{MPEm}, \mathrm{P} 3$ (basal ration with $180 \mathrm{mg} / \mathrm{kg}$ MPEm, P4 (basal ration with $240 \mathrm{mg} / \mathrm{kg}$ MPEm) and repeated four times. The result showed that the use of MPEm in the ration was significant $(\mathrm{p}<0.05)$ on conversion ration, hen-day, egg weight, egg cholesterol, the color of egg yolk, and the thickness of eggshell but not significant on consumption ration, haugh unit, and yolk index score. It can be concluded that MPEm can be used as a feed supplement until $180 \mathrm{ml} / \mathrm{kg}$ ration to give the best on performance production and eggs quality of Sentul chicken.
\end{abstract}

Keywords: Mangosteen peel extract with mineral, performance production, egg quality, Sentul chicken

\section{Introduction}

Sentul chicken is a local Indonesian chicken family that has been cultivated from generation to generation, and so it becomes a wealth of genetic resources of local Indonesian livestock. Sentul chicken is a dual-use chicken that has relatively fast growth and high egg production compared to ordinary local chickens. Sentul chickens can lay eggs around 150 eggs/year (Baktiningsih et al., 2013). The spur production, farmers usually add synthetic antibiotics. Currently, synthetic antibiotics have been banned because they can cause meat and eggs produced to be unsafe for consumption. Therefore, the use of synthetic antibiotics needs to be replaced with natural ingredients which can simultaneously improve performance such as mangosteen peel. Mangosteen is an annual plant whose life span reaches tens of years. The mangosteen tree is evergreen with a height of 6-20 meters. Mangosteen Peel contains 68 types of xantone compounds Aizat et al., (2019) which have many pharmacological functions, especially as natural antioxidants (S Melia, et al., 2019), antibacterial (A Saepudin et al., 2018) and antihyperlipidemic (Alkilany, 2017). Mangosteen Peel contains xanthone compounds at 107.76 mg per $100 \mathrm{~g}$ (Fabiola Gutierrez-Orozco and Mark L Failla,, 2013). Besides, mangosteen functions as an antitumoral, anti-inflammatory, antiallergic, antibacterial, antifungal, and antiviral agent. Xantone has many pharmacological functions such as antioxidant, antiinflammatory and antibacterial, antihyperlipidemic (Alkilany, 2017), and is able to improve blood lipid profile. Xantone compounds can be isolated and taken advantage of by the appropriate extraction methods (Do. Q. D., et al., 2014), one of which is maceration. Mangosteen peel extracted using the maceration method produced total xanton levels of $27.7 \%$ (Andayani et al., 2015).

However, Mangosteen Peel Extract (MPE) contains unsaturated organic acid compounds that have short-chain bonds and have characteristics that are unstable, sensitive, easy to react, and oxidized (Boots AW. Et al., 2008). The way to stabilize it is by supplementing minerals that function as metal catalysts. Supplementation of $\mathrm{Cu}$ and $\mathrm{Zn}$ minerals in the form of $\mathrm{CuCl}_{2} \cdot 2 \mathrm{H}_{2} \mathrm{O}$ and $\mathrm{ZnO}$ mineral salts is intended for two purposes, first for the function of the Mangosteen Peel Extract itself, which is to stabilize its active compounds which are easily ionized and the second purpose of supplementation of $\mathrm{Cu}$ and $\mathrm{Zn}$ minerals as inorganic minerals can form bonding with a protein or carbohydrate group, where minerals can be bound to become organic minerals in the form of $\mathrm{Cu}$ proteinate and $\mathrm{Zn}$ proteinate so that they are easily absorbed by the small intestine, besides, Zn supplementation can also increase the activity of protease enzymes that are regulated by the pancreas (Supriyati, et al., 1999).

\footnotetext{
* Corresponding author e-mail: tuti.widjastuti@unpad.ac.id.
} 
Mangosteen peel extract can be implemented as a feed supplement and then formulated into the ration as a feed supplement in Sentul chicken rations. Xanthone active compounds in MPEm function as antioxidants can change free radical compounds into more stable compounds and can prevent chain reactions from damage caused by free radicals that will have an impact on chicken production (Zaboli, et al., 2013). Besides, xanthones in MPEm can assist in the digestion process by improving the structure of the small intestine villi in the process of absorption of nutrients and suppress the growth of bacteria pathogens inside the intestines (Vemurugan, and Citarasu, 2010). This condition causes the surface area of the intestinal villi to become wider so that the absorption of nutrients can be more and can increase egg production. MPEm also contains flavonoids, anthocyanins, which are water-soluble color pigments. The color produced by anthocyanins ranges from red, blue, to purple, including yellow. Besides that, in mangosteen peel also contains minerals including magnesium $3.3 \%$, copper $0.7 \%$, manganese $1.3 \%$, calcium $1.1 \mathrm{mg}$, Phosphorus $1.7 \mathrm{mg}$, and iron $0.09 \mathrm{mg}$ (Setiawan, D. et al., 2011).

Agung (2014) that MPE administration with a level of $120 \mathrm{mg} / \mathrm{kg}$ body weight/day in broiler chicken rations was able to improve growth performance and increase feed efficiency and carcass percentage. While Widjastuti et al., (2020) the addition of $133 \mathrm{ml} / \mathrm{kg}$ ration MPE without minerals gave a positive response to the production of Sentul chicken eggs. Therefore, the research aims to determine the use of MPE (Garcinia mangostana l) with supplement mineral Zinc and Copper on performan production and eggs quality of sentul chicken.

\section{Material and Methode}

\subsection{Experiment Chicken}

Chicken used in the experiment were 40 Sentul chickens, kept in cages for 12 weeks. Chickens were divided into five treatments and repeated times, each replication containing 2 chickens. The average body weight was 1244.1 grams, with the coefficient of variation in body weight $7.03 \%$.

\subsection{Cage}

Cages used were cage system cages of bamboo as many as 40 units, each unit measuring $40 \mathrm{~cm}$ x $21 \mathrm{~cm}$ x 30 $\mathrm{cm}$ for one chicken.

\subsection{Experiment ration}

The ration was arranged based on the needs of sentul chicken for the phase layer, namely protein and metabolic energy, $17 \%$ protein and $2750 \mathrm{kcal} / \mathrm{kg}$ (Widjastuti $\mathrm{T}$, 1996). The treatment consisted of the use of extract of mangosteen peel (MPEm), namely: P0 $=0 \mathrm{mg} \mathrm{MPEm} / \mathrm{kg}$ ration; $\mathrm{P} 1=60 \mathrm{mg} \mathrm{MPEm} / \mathrm{kg}$ ration; $\mathrm{P} 2=120$ $\mathrm{mgMPEm} / \mathrm{kg}$ ration; $\mathrm{P} 3=180 \mathrm{mg}$ MPEm $/ \mathrm{kg}$ ration and $\mathrm{P} 4$ $240 \mathrm{mg} \mathrm{MPEm} / \mathrm{kg}$. Mangosteen extraction obtained by maceration (Rismana et al., 2014). The macerate (maceration result) of mangosteen peel obtained was temporarily filtered and concentrated using a rotary evaporator to obtain a thick extract. Furthermore, the thick extract of mangosteen peel was dried using a spray and freeze dryer to obtain mangosteen peel extract powder.

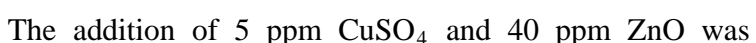
carried out with a ratio of mangosteen fruit extract and catalyst, respectively 1:10.

Table 1. Nutrient Composition Of Basal Diet

\begin{tabular}{ll}
\hline Ingredients & $\%$ \\
\hline Yellow corn & 51.85 \\
Rice bran & 18.52 \\
fish meal & 6.48 \\
soybean meal & 13.89 \\
bone meal & 5.56 \\
Ca CO3 & 3.70 \\
\hline Chemical composition (Calculated) & \\
\hline Crude Protein (\%) & 15.63 \\
Crude Fat (\%) & 5.14 \\
Crude Fiber (\%) & 4.16 \\
Calcium (\%) & 3.28 \\
Phosphorus (\%) & 1.39 \\
Lysine (\%) & 1.06 \\
Methionine (\%) & 0.35 \\
Metabolizable energy, kcal/kg & 2757 \\
\hline
\end{tabular}

\subsection{Experiment Design and Data Analysis}

The study was conducted experimentally with 5 ration treatments containing MPEm with 4 replications. The data were analyzed statistically using a completely randomized design and if there were differences, it was tested by the Duncan test.

\subsection{Observed variables and how they are measured}

- Feed intake was recorded in each 7-day interval.

- Hen day was calculated by dividing number of eggs produced weekly by number of birds and multiplying by $100 \%$.

- Feed conversion is obtained by dividing the amount of feed consumption by weekly total weight of eggs.

- The egg weight produced is weighed and recorded

- Egg Yolk color, as a measure of egg quality, was determined using a Roche colorimetric fan, with scores varying between 1 and 15 .

- Eggshell thickness was measured in three points at the egg equator using a pachymeter and calculating the average among the three points.

- Haugh units were calculated based on the height of the albumen and egg weight. Haugh unit= $100 \mathrm{log}$ HA+7.57-1.7WE 0.37 Where, HA = albumen height, and $\mathrm{WE}=$ egg weight

- Yolk index was calculated by dividing the yolk height by the yolk weight.

- Cholesterol levels of meat were analyzed using the Enzymatic Photometric Test method

\section{Result and discussions}

\subsection{Effect of MPEm treatment in ration on sentul chicken production performance}

The effect of MPEm addition in the ration on Sentul chicken production performance was seen in Table 2. 
Table 2. Average the Ration on Sentul Chicken of Laying Phase

\begin{tabular}{llllll}
\hline Variable & P0 & P1 & P2 & P3 & P4 \\
\hline Consumption ration $(\mathrm{g})$ & $78.85 \pm 3.35 \mathrm{a}$ & $78.06 \pm 3.05 \mathrm{a}$ & $77.34 \pm 2.98 \mathrm{a}$ & $77.05 \pm 3.07 \mathrm{a}$ & $77.00 \pm 3.02 \mathrm{a}$ \\
Hen- day (\%) & $45.13 \pm 4.03 \mathrm{~b}$ & $50.85 \pm 4.09 \mathrm{a}$ & $55.38 \pm 5.09 \mathrm{a}$ & $51.78 \pm 5.08 \mathrm{~b}$ & $47.37 \pm 4.9 \mathrm{ab}$ \\
Convertion ration & $5.32 \pm 0.07 \mathrm{~b}$ & $4.41 \pm 0.09 \mathrm{~b}$ & $3.63 \pm 0.13 \mathrm{c}$ & $3.66 \pm 0.08 \mathrm{c}$ & $3.96 \pm 0.07 \mathrm{c}$ \\
\hline
\end{tabular}

Description: The same letter in the direction of the rows shows no significant difference (P>0.05)

*Duncan test, P0 = without MPEm ; P1 = $60 \mathrm{mg} \mathrm{MPEm/kg} \mathrm{ration} \mathrm{;} \mathrm{P2} \mathrm{=} 120 \mathrm{mg} \mathrm{MPEm} / \mathrm{kg}$ ration; P3 = $180 \mathrm{mg} \mathrm{MPEm} / \mathrm{kg}$ ration; P4 =240 $\mathrm{MPEm} / \mathrm{kg}$ ration

Table 1 . shows the average ration consumption in various treatments has decreased from the control treatment (P0) until P4. The decrease in feed consumption from each treatment was due to the mangosteen peel extract having a distinctive odor that can affect the delicacy of the chicken. Table 1. and Figure 1. shows that the addition of MPEm does not affect feed consumption. These results that feed consumption in each treatment are in the same range. And this gives an idea that the use of MPEm until level $240 \mathrm{mg} / \mathrm{kg}$, did not give a negative effect on the consumption of ration. The mangosteen peel contains a fairly high tannin and can affect the palatability rate of the ration (Ngamsaeng et al., 2006). But in this study the addition of MPEm did not reduce palatability, which could be due to the extraction process with ethanol solvents which could reduce tannin levels to reduce the bitter taste and odor that is typical of mangosteen peel.

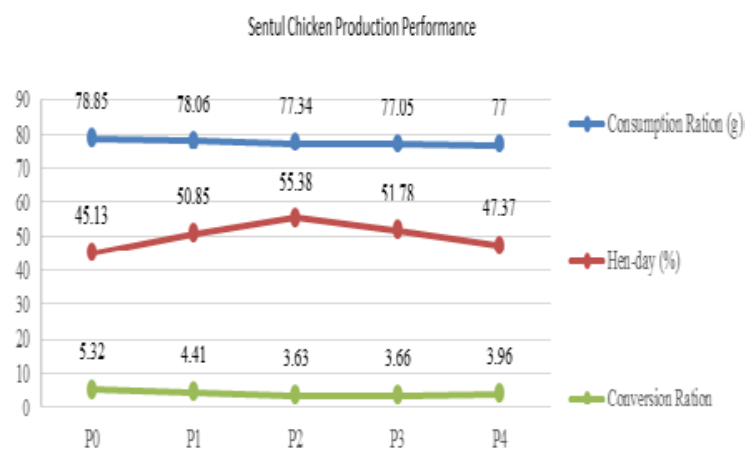

Figure 1. The effect of MPEm addition in the ration on Sentul chicken production performance

The average egg production (Hen-Day) in various treatments has increased, the addition of MPEm in the ration gives a positive response to egg production. Due to the active substance in the MPEm in the form of xanthones functioning as an antioxidant. These antioxidants can prevent free radicals that can cause a decrease in the immune system. Kusumasari et al., (2013) state that antioxidants have an important role to prevent damage caused by free radicals. Xanthones are considered capable of improving the structure of the intestinal villi in the process of absorption of nutrients and suppress the growth of bacteria pathogens inside the intestines. The more xanthones in the body, the more nutrients are absorbed in the body, so that production needs can be met. According Sreedam Chandra Das (2012) that xanthone derivatives like mangostin, isomangostin and mangostin triacetate are known to possess significant anti-inflammatory activities. However, MPE contains methyl esters of unsaturated organic acids that are easily oxidized. Therefore, $\mathrm{Cu}$ and Zn supplementation will play a role in activating bioactive compounds contained in MPE which is reactive, thus making the ionization in the digestive tract higher and can be utilized optimally resulting in egg production.

The average value of feed conversion with the addition of MPEm has decreased. FCR values in the MPEm treatment ranged from 3.63 to 4.41 lower than the control ration without the addition of MPEm. The addition of MPEm at doses of 120-240 mg indicates a better and more efficient quality of ration which is indicated by the lower FCR value. Xanthone compounds can inhibit the growth of pathogenic microbes that cause disease so that the digestive system of Sentul chickens can work optimally and the utilization of rations will be more efficient. According Toghyani (2010) the addition of bioactive compounds to herbs can increase appetite stimulation and food intake, increase endogenous digestive enzmes, immune response activities, anti-oxidants, and antimicrobials. With this role, the nutrients can be utilized to produce eggs more effectively. Xanthone compounds in MPEm at optimal doses have an effective role in improving the structure of intestinal villi in the absorption of feed nutrients (Adriani et al., 2018). Increased absorption of nutrients by intestinal villi increases egg production and decreases the value of feed conversion.

\subsection{Effect of MPEm treatment in ration on Sentul Chicken egg quality}

Data on the effect of adding MPEm in the ration to the variables of the quality sentul chicken eggs can be seen in Table 3. 
Table 3. Effect MPEm in The Ration On Egg Quality

\begin{tabular}{|c|c|c|c|c|c|}
\hline Variable & $\mathrm{P} 0$ & $\mathrm{P} 1$ & $\mathrm{P} 2$ & P3 & $\mathrm{P} 4$ \\
\hline Egg weight (g) & $40.87 \pm 8.07$ a & $43.89 \pm 9.08 b$ & $44.00 \pm 10.04 \mathrm{~b}$ & $44.37 \pm 9.07 \mathrm{~b}$ & $44.23 \pm 9.04 b$ \\
\hline Shell Thickness (mn) & $0.26 \pm 0.09 \mathrm{a}$ & $0.31 \pm 0.1 b$ & $0.32 \pm 0.12 b$ & $0.32+0.19 b$ & $0.30 \pm 0.99 \mathrm{~b}$ \\
\hline Haugh Unit Value & $78.47 \pm 10.08 \mathrm{a}$ & $78.66 \pm 9.08 \mathrm{a}$ & $78.88+8.09 a$ & $79.73 \pm 7.09 \mathrm{a}$ & $79.22 \pm 8.09 \mathrm{a}$ \\
\hline Yolk index & $0.44+0.12 \mathrm{a}$ & $0.41 \pm 0.14 a$ & $0.41+0.18 a$ & $0.44 \pm 0.19 a$ & $0.42 \pm 0.19 \mathrm{a}$ \\
\hline Color Yolk score & $9 \pm 2.8 \mathrm{a}$ & $10 \pm 2.9 \mathrm{a}$ & $11+2.4 b$ & $11 \pm 3.0 \mathrm{~b}$ & $11+2.9 \mathrm{~b}$ \\
\hline Egg yolk cholesterol (mg/100g) & $122.25+10.9 a$ & $125.62 \pm 11.9 a$ & $109.49+11 b$ & $102.46 \pm 12.06 \mathrm{~b}$ & $102.24 \pm 11.03 \_b$ \\
\hline
\end{tabular}

Description: The same letter in the direction of the rows shows no significant difference $(\mathrm{P}>0.05)$

*Duncan test, P0 = without MPEm ; P1 = $60 \mathrm{mg} \mathrm{MPEm} / \mathrm{kg}$ ration ; P2 = $120 \mathrm{mg} \mathrm{MPEm} / \mathrm{kg}$ ration; P3 = 180mg MPEm/kg ration; P4 =240 $\mathrm{MPEm} / \mathrm{kg}$ ration

Egg quality measurements are summarized in Table 3 after 4 weeks of treatment. Analysis of variance showed that MPEm in real ration increased the egg weight compared to control. These results indicate that a higher dose of MPEM can increase egg weight. This is due to mangosteen peel containing xanthones, $6.45 \%$ protein, and $3.02 \%$ fat. Xanthones function as an antibacterial that can suppress the growth of pathogenic bacteria in the intestine, and can improve the structure of intestinal villi in the process of absorption of nutrients (Vemurugan and Citarasu, 2010). Thus, the presence of xanthones makes the condition of the digestive tract better and the process of absorption of nutrients in feed, especially protein and fat, which are the most important food factors that affect egg weight more optimally. This was supported by Argo and Mangisah, (2013) that egg weight was influenced by protein, fat, and essential amino acids contained in the ration. Another factor that leads to increased egg weight is the presence of antioxidants contained in the MPE. Antioxidants can capture free radicals in the body so that the presence of an antioxidant can suppress the emergence of free radicals. In line with Kusumasari et al., (2013) that free radical damage can be prevented by antioxidants. Increased free radicals cause the body's defense ability to decrease so that it can trigger stress on livestock that has an impact on decreasing egg production, especially egg weight. This condition shows that the xanthone compound at optimal dosage has the potential as a natural antibiotic in poultry through antibacterial and antioxidant mechanisms so that it will improve the immune system of Sentul chickens, eventually the maximum nutrient intake and an increase in egg weight.

The average range of shell thickness is $0.26-0.32$. The range is in the range of chicken eggshell thickness in general. MPEm administration up to $240 \mathrm{mg} / \mathrm{kg}$ in the diet significantly $(\mathrm{P}<0.05)$ on the shell thickness. This can be caused by mangosteen extract containing $11 \mathrm{mg} \mathrm{Ca}$ minerals, and $17 \mathrm{mg}$ Phosphorus, with the supplementation of $\mathrm{Cu}$ and $\mathrm{Zn}$ minerals in the form of $\mathrm{CuCl}_{2} \cdot 2 \mathrm{H}_{2} \mathrm{O}$ and $\mathrm{ZnO}$ mineral salts, will play a role to activate the bioactive contained in the mangosteen peel extract which is reactive, so that makes ionization in the digestive tract higher and can be optimally utilized right on target, and will increase the thickness of Sentul.

The average value of $\mathrm{HU}$ is between 78.47-79.22 and the average yolk index is $0.41-0.44$. The effect of adding MPEm on the ration did not significantly affect the HU value and egg yolk index. Yolk index and albumen are influenced by protein content in feed. Based on the research results, levels of protein (15\%) in feed and feed intake (unpublished data) were not significantly different between treatments. So, the protein consumption for each treatment is the same, which causes the amino acid content in the egg to be the same, which in turn produces an egg with the same freshness. This condition will produce egg yolk index and haugh unit value, relatively the same between treatments. Following the opinion of Lengkey et al., (2012) that the Yolk Index and Haught Unit values are used to determine the freshness of eggs.

Figure 2. Effect of Adding MPEm in The Ration to The

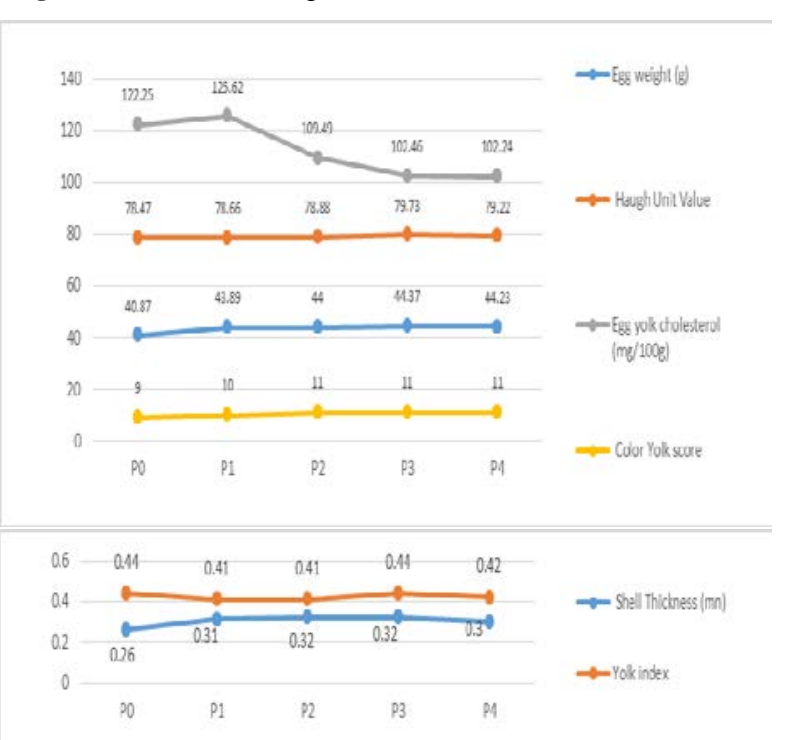

Variables of The Quality Sentul Chicken Eggs

Table 3 and Figure 2. shows that results of the KruskalWallis test showed that MPEm in the ration significantly improved color of the yolk of Sentul chicken. The content of xanthones and xanthophyll contained in the feed able to improve the structure of the intestinal villi in the process of absorption of nutrients (Vemurugan and Citarasu, 2010). Thus, the existence of xanthones will make the digestive tract conditions better and the process of absorption of nutrients in the feed, especially xanthophyll which is a colorant in egg yolks, becomes more optimal. The color pigment will be absorbed by the small intestine digestive organs and transported in the blood circulation and then circulated to the target that needs, namely the egg yolk. Color pigments will be absorbed by the digestive organs of the small intestine and transported.

The current study shows that MPEm reduced the level of yolk egg cholesterol. Following Mangisah (2003) that normal chicken egg cholesterol levels range from 125-200 $\mathrm{mg} / \mathrm{dL}$. The process of cholesterol synthesis. The process of cholesterol synthesis starts from acetyl CoA which is the result of carbohydrate or fat metabolism. Xanthones in MPEm work through the mechanism of inhibiting the 
activity of HMG CoA reductase enzymes, which can cause inhibition of cholesterol biosynthesis (Botham et al., 2015). Among phenolic compounds found in MPEm are flavonoids which have been studied extensively because of their capability to moderate some metabolic process such carbohydrate and lipid metabolism. Mohamed et al (2019) that phenolic compounds could be a major determinant of antioxidant potentials of foods and could, therefore, be a natural source of antioxidants.

Flavonoids are antioxidants that can reduce blood cholesterol levels, the mechanism by which flavonoids inhibit cholesterol synthesis through HMG CoA reductase inhibitors (Metwally, 2009). In addition to xanthones, MPEm also contains lipophilic saponins that can dissolve fats and emulsions that can reduce blood cholesterol levels due to hypercholesterolemia (Francis et al., 2002 ; Adriani et al., 2018).

\section{Conclusions}

It can be concluded that:

1. The use of MPEm in ration was significant $(\mathrm{p}<0.05)$ on conversion ration, hen-day, egg weight, the thickness of eggshell, the color of egg yolk and egg cholesterol but not significant on yolk index score, consumption ration and haugh unit.

2. MPEm can be used as a feed supplement until 180 $\mathrm{mg} / \mathrm{kg}$ ration to give the best on performance production and egg quality of Sentul chicken.

\section{Acknowledgements}

This research was funded by the Grand Research Academic Leadership project from Universitas Padjadjaran to Tuti Widjastuti. I would like to thank Lovita Adriani, Indrawati Yudha Asmara, Iwan Setiawan, Abun, Leni Nurlaeni who helped write this paper.

\section{References}

Adriani L, Widjastuti T, Nurdianti, RR, Wiradimadja R. 2018. Effects of mangosteen peel extract (garcinia mangostana l.) on blood lipid of sentul chicken growth phase. The 3rd International Conference of Integrated Intellectual Community (ICONIC). Jerman.

Agung AC. 2014. Comparison of the activity of mangosteen peel extract and various antioxidants on broiler performance.JPPT., 15 (1): 68-74.

Aizat WM, Jamil IN, Ahmad HFH, Noor NM. 2019. Recent updates on metabolite composition and medicinal benefits of mangosteen plant. Peer J., 7: e6324.

Alkilany SA, Elin YN, Neng FK and Ketut AI. 2017. Antihyperlidemic effects of mangosteen (garcinia mangostana l.) pericarp ethanolic extract in high-carbohydrate wistar rats. Journal Of Natural Remedies., 17 (4) : 165-173

Andayani R, Novita R and Verawati. 2015. Effect of extraction methods on total xanthones in mangosteen (garcinia mangostana 1.) fruit rind extract by ultraviolet spectrophotometry. Prosiciding Conference \& Workshop. Universitas Andalas, Padang.

Argo LB. dan Mangisah I. 2013. Physical quality of phase i laying arab chicken eggs with various levels of azolla microphylla. Animal Agricultural Journal., 2(1): 445-457.

Baktiningsih S, Mugiyono S and Saleh DM. 2013. Egg production of various types of Sentul chickens at the Ciung Wanara
Livestock Group Association, Ciamis District, Ciamis Regency. JIPT., 1(3): 993-1000.

Boots AW, Haenen GRMM, Bast A. 2008. Health effects of quercetin: From antioxidant to nutraceutical. Eur J Pharmacol., 585: 325-327.

Botham KM, Mayes PA. Cholesterol synthesis, transport, \& excretion. dalam Murray RK, Bender DA, Botham KM, Kennelly PJ, Rodwell VW, Weil PA. 2015. Harper's illustrated biochemistry. 30th ed. The Mc Graw-Hill education. 266-72.

Do QD, Angkawijaya AE, Tran NPL, Huynh LH. Soetarredjo. FE, Ismadji. S, Ju. YH. 2014. Effect of extraction solvent on total phenol content, total flavonoid content and antioxidant activity of Limnophila aromatic. J. Food Drug Anal., 22(3). 296 - 302.

Fabiola GO, Mark LF. 2013. Biological activities and bioavailability of mangosteen xanthones: a critical review of the current evidence. Nutrients:13., 5(8) : 3163.

Francis G. Kerem Z, Makkar HPS, Becker K, 2002. The biological action of saponins in animal systems: a review. $B r . J$. Nutr., 88: 587-605.

Kusumasari DP, Mangisah I, dan Estiningdriati I. 2013. Effect of Addition Vitamin A and Vitamin E in Diet on Egg Weight and Embryo Mortality in Kedu Black Hens. Anim. Agric. J., 2(1): 191200.

Lengkey HAW, Widjastuti T, Darana S, 2012, the effect of storage time in different temperature on native chicken egg haugh unit and yolk index. Scientific Papers. Series D. Animal Science., Vol. LV, ISSN-L 2285-5750, 173-175.

Mangisah I. 2003. Use of C. domestica and C. xanthorrhiza in BroilerDiet as Agent for Decrease of Meat Cholesterol. JLITBANG., 1(2): 96-101.

Marisca EG, Bambang P, Sutiman BS, Wahyu W, Kusworini H. 2019. Xanthones Analysis and Antioxidant Activity Analysis (Applying ESR) of Six Different Maturity Levels of Mangosteen Rind Extract (Garcinia mangostana Linn.). Pharmacogn J., 11(2): 369-373

Metwally MAA. 2016. Effects of Garlic (Allium sativum) on Some Antioxidant Activities in Tilapia Nilotica (Oreochromis niloticus). World J. Fish Mar. Sci., 1 : 56-64.

Mohamed AM, Fawzy G. K and Enas I. M. 2019. Phenolic Compounds, Antioxidant and Antibacterial Activities of Rhus flexicaulis Baker. Jordan Journal of Biological Sciences., 12 (1) : $17-21$

Ngamsaeng, M. Wanapat and S. Khampa. 2006. Effects of Mangosteen Peel (Garcinia mangostana) Supplementation on Rumen Ecology, Microbial Protein Synthesis, Digestibility and Voluntary Feed Intake in Cattle. Pakistan Journal of Nutrition., 5: 445-452.

Rismana, Eriawan, Kusumaningrum, Susi, Bunga, Olivia, Nizar, Marhamah. 2014. Determination Of Antiacnes Activity Of Chitosan - Garcinia Mangostana Extract Nanoparticles. Media of Health research \& Development., 24 (1) : 19-27

S Melia, D Novia, I Juliyarsi, and E Purwat. 2019. The characteristics of the pericarp of garcinia mangostana (mangosteen) extract as natural antioxidants in rendang. International Conference on Animal Production for Food Sustainability. IOP Conf. Series: Earth and Environmental Science. 287.

Saepudin A, Natawijaya D, Hartini E and Iskandar R. 2018. Evaluation of antibacterial activity of mangosteen (Garcinia mangostana L.) pericarp extract against rice leaf blight bacteria (Xanthomonas oryzae pv. oryzae) at various temperatures and durations of fruit storage. IOP Conference Series: Earth and Environmental Science. 250. 
Setiawan DV, Djunaedi, dan Sudjarwo. 2011. Effect Of Addition Mangosteen Peel Powder (Garcinia Mangostana L.) As Feed Additive To The Production Performance Of Male Mojosari Duck. Article of Universitas Brawijaya. Malang. Indonesia.

Sreedam CD, Subrata B, Sumon Roy, Sajal KS, Md. Saiful Islam and Sitesh CB. 2012. Analgesic and Anti-inflammatory Activities of Ethanolic Root Extract of Swertia chirata (Gentianaceae) Jordan Journal of Biological Sciences. 5 (1) : 31 - 36

Supriyati D, Yulistiani, Wina dan Haryanto. 1999. Micro mineral supplementation in an effort to increase sheep productivity. Indonesian Journal of Animal and Veterinary Sciences., 11-30.

Toghyani M, Toghyani, Gheisari, Ghalamkari, and Mohammad R. 2010. Growth performance, serum biochemistry and blood hematology of broiler chicks fed different levels of black seed (Nigella sativa) and peppermint (Mentha piperita). Livestock Science., 129 (1):173-178.
Vemurugan S. And T. Citarasu. 2010. Effect of herbal antibacterial extracts on the gut floral changes in indian white shrimp Fenneropenaeus indicus. Rom. Biotech. Lett., 5709-5717.

Widjastuti T, Setiawan I, Abun, Asmara IY, Roostita LB. 2020. application of mangosteen peel extract (Garcinia mangostana l) as feed additive in ration for performance production and egg quality of sentul chicken. Internasional Journal on Anvenced Science, Enginering and Information Technology., 10 (2) : 789794.

Widjastuti T. 1996. Determination of Efficiency of Protein Use, Protein Energy Needs for Growth and Production of Sentul Chicken Eggs on Cage System and Litter System. [Dissertation]. Postgraduate Program, Universitas Padjadjaran, Bandung.

Zaboli GZ, Bilondi and Miri. 2013. The effect of dietary antioxidant supplements on abdominal fat deposition in broilers. Life Sci. J., 10 : 328-333. 